\title{
A „NÉPI DEMOKRÁCIA” VISZONYA A PEDAGÓGUSOKHOZ (1946-1948)
}

\section{RELATION OF 'PEOPLE'S DEMOCRACY' TO PEDAGOGUES (1946-1948)}

\author{
N. Szabó József \\ a politikatudomány kandidátusa, dr. habil professor emeritus, Nyíregyházi Egyetem \\ n.szabo.jozsef@nye.hu
}

\section{ÖSSZEFOGLALÁS}

A pedagógusok többsége politikai modelljének perspektivikus megvalósítását a magántulajdonon alapuló politikai berendezkedést megvalósítani szándékozó Független Kisgazdapárt programjában látta, ezért erre szavazott.

A vereséggel felérő választások után a Magyar Kommunista Párt (MKP) értelmiségpolitikájában a pedagógusok, különösen a tanítók megnyerése kiemelt szerepet kapott. A Nemzeti Paraszt Párt is nagy fontosságot tulajdonított a tanítóknak. A Kisgazdapárt a pedagógusok támogatottsága miatt nem foglalkozott kiemelten a csoporttal. Az MKP részéről verbálisan hangoztatott ígéretek ellenére a pedagógusok problémái nem oldódtak meg

A kommunisták számára a pedagógusok politikai befolyásolása első számú szempont lett, mert a parasztság megnyerésében kiemelt szerepet szántak a tanítóknak. 1947 nyarától már a pártba való beszervezés is centrális kérdéssé vált. Mindezek ellenére az MKP befolyása csekély maradt. 1946 ősze és 1947 ősze között nem nőtt a kommunisták befolyása a pedagógusok körében, de a szociáldemokraták sem értek el lényeges eredményeket. A diktatúra kiépülésének kezdetén, a kb. 40000 pedagógusból 2800 volt MKP-tag, a Magyar Dolgozók Pártja létrejöttekor $12-18 \%$ volt párttag.

1945-től elsősorban egzisztenciális okokból és politikai nyomásra már növekedés észlelhető a pedagógusok között a pártba lépés terén.

\section{ABSTRACT}

The majority of pedagogues were of the opinion that their favoured political model could be implemented by the Independent Smallholders' Party which strove for a political system based on private property.

After the communists' highly unsuccessful elections results of 1945, the intelligentsia policy of the Hungarian Communist Party (HCP) focused on winning over teachers, predominantly primary school teachers. The party placed a high emphasis on solving the teachers' problems. Similarly, teachers were held in high esteem by the National Farmers' Party as well. The Independent Smallholders' Party did not care that much about teachers. Despite all the communists' oral promises, teachers' existential problems were not solved.

Communists wanted to influence teachers because they thought teachers should play a vital role in winning the favour of farmers. From the summer of 1947 the party intensely recruited 
teachers as party members. Nevertheless, they could not create a significant influencing force on teachers.

In 1947, just a rather insignificant fracture of teachers were politically involved. At the beginning of the dictatorship out of 40,000 teachers only 2,800 were members of the Hungarian Communist Party. When Hungarian Workers' Party was founded $12-18 \%$ of them were party members. Compared to other professional groups like physicians or engineers, the gain in political influence of the HCP was decidedly slim. From 1949 on, more and more teachers joined the party, mainly for existential reasons.

Kulcsszavak: politikai pártok és az értelmiség a rendszerváltás idején, pedagógus-politika a demokráciában, a "népi demokráciába vezető út", a pedagógusok politikai érdeke a kiépülő diktatúrában

Keywords: political parties and the intelligentsia at the period of the political change, teacher policy in democracy; 'heading for the people's democracy', political interests of teachers in the developing dictatorship

\section{A DEMOKRATIKUS ÁTALAKULÁS ELSŐ ÉVEI}

A háború után a politikai erők és az értelmiség között tényleges konfliktushelyzet mindaddig nem keletkezett, amíg a pártok közti küzdelem nem kapott politikai jelleget. A hatalmi szempontok 1945 nyarán történő megjelenése azonban jól elhatárolható sokszínúséget eredményezett a pártoknak az értelmiséghez, illetve a pedagógusokhoz való viszonyában.

A politikai harc 1945 nyarán megindult kibontakozása és a pártok osztályjellegének kirajzolódását követően megkezdődött az értelmiség pártokba szervezése. A pártok és az értelmiség ,találkozása” attól is függött, hogy sikerül-e a régi funkció és a demokráciában betöltendő szerep közötti ellentmondást feloldani, illetve sikerül-e az értelmiség érdekeit számukra minél elfogadhatóbban képviselni.

Az 1945. évi őszi választási kampányok idején a pártok már igyekeztek az értelmiség legkülönbözőbb csoportjait megnyerni. Ebben a vetélkedésben a legnagyobb aktivitást a Magyar Kommunista Párt (MKP) és a Független Kisgazdapárt (FKGP) tanúsította. Az értelmiség többsége politikai modellje perspektivikus megvalósítójának a magántulajdonon alapuló polgári demokráciát a leginkább képviselő FKGP-ben látta, ezért a választásokon rá szavazott. Az intelligenciának azon csoportjai, akiknek politikai elképzelései az FKGP-vel nem voltak összeegyeztethetőek, azok sem az MKP-re, hanem a Szociáldemokrata Pártra (SZDP) vagy a Nemzeti Paraszt Pártra (NPP) szavaztak. A Kommunista Párt mellé így az értelmiségnek csupán kis hányada állt.

Az MKP értelmiségi politikájában a pedagógusok - különösen a tanítók - megkülönböztetett szerepet kaptak. Az MKP és a csoport között azonban 1946 elején 
konfliktus keletkezett azáltal, hogy a pedagógusok nagyon súlyos egzisztenciális problémái nem oldódtak meg, ami tavasszal a Sportcsarnokban összejövetelhez, majd sztrájkhoz vezetett. A Magyar Kommunista Párt nem értett egyet a pedagógusok véleménynyilvánításának azzal a formájával, ami a Sportcsarnokban történt. Hasonlóan elítélően nyilatkozott a Szociáldemokrata Párt is. A Független Kisgazdapárt viszont támogatta a sportcsarnoki megmozdulást, és felvállalta a pedagógusok érdekeinek védelmét.

A munkáspártok és a pedagógusok között ezáltal feszültség alakult ki, annak ellenére, hogy baloldalon kerülni igyekeztek az összeütközéseket.

A feszültségeket a baloldali politikai erők és a pedagógusok között az igazolásokat „hatékonyabbá” tevő B-lista rendelet kiadása váltotta ki. Az 1946. március 1-jén megjelent az 500/1946. sz. ME „tisztogatási” rendelet szerint július 5-ig a minisztériumoknak meg kell állapítaniuk, hogy a tárcájuk körébe tartozó intézményekből hány főt kell elbocsátani. (Magyar Közlöny, 1946. május 15.) A B-listázás során mintegy 60000 személyt, többségében hivatalnokot távolítottak el. A B-listázás miatt a pedagógusok körül is viták alakultak ki. Mind a sajtóban, mind a parlamentben ekkor a baloldal részéről - különösen az MKP és az SZDP oldaláról - éles bírálatok érték a nevelői kart és az oktatásügy irányítóit. Pedagógusellenes véleményekkel már a B-lista megjelenése előtt is találkozunk az SZDP egyes baloldali politikusai, például Bóka László irodalomtörténész részéről (Jakab, 1979, 134.).

A pedagógusok és a munkáspártok közti közeledésnek nem kedvezett az sem, hogy a stabilizáció után, a forint 1946. augusztusi bevezetését követően az értelmiség szakmai kategóriái között továbbra is a pedagógusok voltak a legrosszabb helyzetben. Fizetésük 200 forint körül mozgott - így alatta maradt valamennyi bérből élő réteg fizetésének -, és többségük számára az új rendszer a létminimumot sem biztosította. Megjelentek ugyan illetményrendeletek, a pedagógusok azonban megmaradtak a rosszul fizetett kategóriákban. Az ország 35000 pedagógusa közül 20000 fizetése 204 forint volt, de 3600-nak csak 159 forintot tett ki a bére. A munkások keresete 50-60\%-kal, az értelmiségé viszont csak 20-40\%kal emelkedett (Jakab, 1979, 146.).

Mivel a pedagógusok életszínvonala nem emelkedett, és politikai felfogásuk alapján sem voltak baloldali beállítottságúak, ezért nem volt elvárható tőlük, hogy a munkáspártok mellé álljanak. A negatív vélemények azonossága a pedagógusokkal kapcsolatosan nemcsak közelített, hanem az oktatásirányítás terén egy közös „koncepció” is formálódott a kép párt között. Különösen az SZDP ambicionálta az együttes fellépést. 1946. augusztus 15-én az SZDP Nevelői Csoportjának elnöke Dallay Antal Károly, Rákosi Mátyás pártfötitkárnak, kommunista államminiszternek küldött leveléből ez egyértelmüen kiolvasható. Dallay úgy látta, hogy a demokratikus szemléletủ társadalomnak a nevelése csak az ifjúság nevelésének teljes reformján keresztül érhető el, ami azonban csak a Magyar Kommu- 
nista Párt és a Szociáldemokrata Párt nevelőinek teljes és tökéletes együttműködésével és a minisztérium átvételével biztosítható. Dallay ezért a fenti témában kihallgatást kért Rákosi Mátyástól (PTI Arch. 274-24/11). A nyomás hatására a parasztpárti Keresztury Dezső 1946 öszén lemondott, de 1947 tavaszáig vezette a Vallás- és Közoktatásügyi Minisztériumot (VKM).

\section{SZAKÍTÁS A DEMOKRÁCIÁVAL}

Az 1945-1946-os év sikertelen kommunista értelmiségi politikája ellenére az MKP 1946 nyarán nem foglalkozott társadalmi fontosságának megfelelően az értelmiséggel. Az 1946. szeptember 28. - október 1. között megtartott stratégiai jelentőségü III. kongresszuson - ahol a kommunisták szakítottak a demokrácia addigi, általuk is elfogadható gyakorlatával, és meghirdették a népi demokráciába való átmenetet - sem politikai súlyának megfelelően értékelték az értelmiséget. A kongresszus után nemsokára azonban megnőtt az értelmiségpolitika jelentősége (Rákosi-Szabó, 1967, 262-295.). Első helyen álltak a pedagógusok, köztük is a vidéki óvónők, tanítók, tanárok. Az MKP a siker érdekében országos akciót szándékozott tartani a pedagógusok gazdasági helyzetének javításáért, de elsősorban a státuszrendezésért. E koncepció része volt továbbá a pedagógusok legfontosabb kulturális követelésének előtérbe állítása. Az MKP 1946 októberében létrehozta a párt Értelmiségi Osztályát, amelynek vezetöje Orbán László lett, munkatársai között találjuk többek között a híres nyelvészt, Szemerényi Oszvaldot (Jakab, 1979, 151.).

Az értelmiségi befolyást kívánta a párt azzal is növelni, hogy az MKP 1946. december 2-án útmutatást készített egy országos pedagógus kampány levezetésére. A kampány indításában fontos szerepet szánt Losonczy Gézának, az értelmiséggel kapcsolatot tartó politikusnak és a párt lapjának, a Szabad Népnek (Szabad Nép, 1946, december).

Nem véletlen, hogy az értelmiségi munka elhanyagolása és a nem megfelelő befolyás miatt az MKP Értelmiségi Osztálya felhívta a figyelmet arra, hogy a III. kongresszuson Rákosi Mátyás fötitkár és Farkas Mihály fötitkárhelyettes referátumban azt állapította meg, hogy a leginkább elmaradt munkaterület az értelmiségi munka volt. Az osztály arra is figyelmeztetett, hogy a párt nagy hátrányt szenvedett az értelmiségre gyakorolt tömegbefolyás területen a többi párttal szemben, ami abban is megmutatkozott, hogy az FKGP és az SZDP külön szakmai csoportokat szervezett, és agitációt folytatott. Az Értelmiségi Osztály újólag megfogalmazta, hogy a népi demokrácia szempontjából fontos az értelmiség megnyerése (PTI Arch. 274-24/2).

Az Értelmiségi Osztály nemcsak az értelmiségi munka fontosságára és átszervezésére hívta fel a figyelmet, hanem arra is emlékeztetett, hogy a parasztság megnyerése szempontjából az orvosok mellett a pedagógusokra is fokozott fi- 
gyelmet kell fordítani. Az MKP számára politikailag fontossá váló pedagógusok körében pozícióinak javítása érdekében ezért ankétokat és gyüléseket szándékozott szervezni (PTI Arch. 274-24/2). 1946. november 1-jén az Országos Propaganda Osztály a tanítók megnyeréséért a Szervező Bizottságnak országos méretü kampány megindítását javasolta. A kampány keretében kívánták kidolgozni a párt követeléseit a tanítók helyzetének orvoslására. Brossúrák kiadását és a sajtó „beállítását" is kezdeményezték. Aktívát terveztek a tanítók gazdasági problémáinak javítására és követeléseinek ismertetésére. A tanítókkal és családtagjaikkal kapcsolatos lépéseknél be szándékoztak vonni szakszervezeteket is (PTI Arch. 274-21/118).

A Magyar Kommunista Párt a falvak, a vidék politikai megnyerésében kiemelkedő szerepet szánt a Szabad Föld Téli Esték kampányának is. A rendezvénysorozat révén a párt lehetőséget kívánt adni a falusi szervezeteknek az értelmiséghez való viszonyuk javítására (PTI Arch. 274-21/48).

A remélt siker érdekében az Értelmiségi Osztály minden nagyobb városban, főként ahol sok pedagógus volt, december 1. és 20. között gyüléseket szándékozott tartani. Az osztály elképzelése szerint két elöadást kell tartani: egy politikai - kultúrpolitikai jellegűt és egy pedagógiait. Azt is kérték, hogy a szónok megfelelő színvonalon tudjon az „értelmiség nyelvén” beszélni, és azt is fontosnak tartották, hogy szimpátiát keltsen a Magyar Kommunista Párt iránt. Azt is fontosnak tartották, hogy meghívókkal személyesen is invitálják az igazgatókat és minden pedagógust. A nagygyüléseket „nemzetivé” kívánták tenni azáltal, hogy a párthelységekben legyen jelen a piros-fehér-zöld szín. Arra is rámutattak, hogy a nagygyülések előkészítésére használják fel a helyi sajtót, foglalkozzanak a pedagógusok helyzetével és panaszaival. Az Értelmiségi Osztály továbbá azt is javasolta, hogy a Szabad Nép a következö napokban még többet foglalkozzon a pedagógusok gondjaival, ezért felhívta az összes pártszervezet figyelmét az akciók fontosságára (PTI Arch. 274-24/11).

Az MKP értelmiségpolitikájának nem reális kidolgozására utalnak ugyanakkor a párt egyes elképzelései és lépései. Brosúrák készítése, propaganda-előadások tartása ugyanis alapvetően nem módosítják társadalmi rétegek vagy csoportok politikai véleményét, illetve azok megváltoztatását sem érik el ezekkel a módszerekkel. A kommunista politikai modelltől távol álló tanítóság felfogása azért nem volt átalakítható azokkal az elképzelésekkel, amelyekkel az MKP a tanítókhoz, illetve az egész pedagógus társadalomhoz közelített.

A gyenge kommunista befolyással is magyarázható, hogy az MKP pedagógusokkal kapcsolatos politikája a siker érdekében 1946. december végén másfajta lendületet kívánt venni. A Magyar Kommunista Párt Békés megyei szervezete által 1946. december 16-án Gyulán összehívott pedagógus nagygyülésen a következő határozatot hozta, és kérte a Központi Vezetőséget (KV), hogy az abban foglaltakat tegye magáévá, és kövessen el mindent azoknak a haladéktalan meg- 
valósításáért. Ezek között szerepelt: Üdvözlik a pedagógusok anyagi és erkölcsi felemelése érdekében tett kezdeményező lépéseket. Továbbá fontosnak tartották annak hangsúlyozását, hogy sérelmes a 2500/1945. sz. rendelet, mert általa hátrányos körülmények közé kerültek a pedagógusok a többi köztisztviselővel szemben, ezért követelték a nevelői státus újra rendezését, valamint nevelői pótlék bevezetését. A békési gyülés kérte a $\mathrm{KV}$-t, hasson oda, hogy a nyugdíjasok a nyugdíj 100\%-át kapják meg. Ezenkívül kezdeményezte az illetmények egy összegben való kifizetését a hónap elején. A Békés megyei kommunisták azt is indítványozták, hogy a pedagógus gyerekek minden iskolafajtában tandíjmentességben részesüljenek, és elvárták a Vallás és Közoktatási Minisztériumtól a falusi és tanyai tanítók fokozottabb megbecsülését.

A továbbiakban pedig kezdeményezték a VKM tárca „betöltését”, mert csak így látták biztosítottnak az általános iskola további kiépítését, a titkos minősítések megszüntetését, valamint a tanítói és kántori szolgálat szétválasztását. Fontos célként fogalmazták meg az egységes alapokon nyugvó nevelőképzés megvalósítását és a középiskoláknak a gazdasági és társadalmi szükségleteket figyelembe vevő reformját. Azt is fontosnak tartották, hogy az újonnan kinevezett tanítók haladéktalanul kapják meg illetményüket, és hajtsák végre a tanügyigazgatás és felügyelet reformját (PTI Arch. 274-24/11).

Az Értelmiségi Osztály 1946-1947 fordulójától azért is tulajdonított kiemelt jelentőséget a pedagógusoknak, mert - mint megjegyezte - az értelmiség 50\%-a pedagógusokból áll, és ezért komoly politikai erőt képviselnek. Az MKP politikájában az első számú szempont továbbra is a parasztság megnyerésének elősegítése volt, a második helyen az ifjúság nevelése állt, a harmadik helyre pedig a köznevelés demokratizálása került. Ezeknek az érdekeknek lett alárendelve a kommunista szövetségi politika. Az Értelmiségi Osztály ezért úgy látta, hogy a pártnak a gazdasági nehézségek ellenére mindent meg kell tennie a pedagógusok anyagi és kulturális megsegítéséért. A várt sikerek azonban nem jelentkeztek. Az osztály szerint ennek egyrészt az volt az oka, hogy a párt nem támaszkodott szervezett kommunista csoportra, másodsorban pedig az, hogy helyi és kerületi szinten a pártszervek vezetői értelmiségellenes politikát folytattak.

Az első probléma kiküszöbölése az Értelmiségi Osztály szerint azzal megtörtént, hogy 1947. március 21-én megalakult a Magyar Kommunista Párt pedagógus csoportja választott elnökséggel és vezetőséggel, és megkezdte a kerületi és vidéki kommunista pedagóguscsoportok megszervezését. A pedagóguscsoport létrehozása lényeges változást jelentett a párt politikájában azért is, mert eddig a pedagógusok elsősorban mint a parasztság megnyerésében szerepet játszandó csoport jött számításba. A pedagógusok ezután már nemcsak mint szövetségi politikai tényező kerültek a kommunista politika fókuszába, hanem mint a pártba beszervezendő, beléptetendő politikai szereplők váltak fontossá. A nagy kérdés az volt, hogy az MKP miként kalkulált a pedagógusokkal? Úgy hogy „tudatos” 
kommunistákat akart soraiba vezetni a nagy tömegủ beléptetésekkel, vagy függő helyzetbe juttatott alkalmazottakat kívánt elkötelezetté tenni. A tervezett politikai lépéseknek nemcsak taktikai, hanem hosszú távú stratégiai következményei is lehettek és lettek az elkövetkező években.

A változtatási szándék ellenére a Magyar Kommunista Párt befolyása a pedagógusokra csekély maradt, mert például Budapesten a 10000 pedagógusból mindössze 500 fö volt az MKP tagja, ami a pedagógusok 5\%-át jelentette. Vidéken a 25000 pedagógusból pedig mindösszesen 750 -en voltak a párt tagjai (PTI Arch. 274-24/2).

A pedagógusok közti kommunista befolyással, annak okai egy részével az Értelmiségi Osztály is tisztában lehetett, amikor megállapította, hogy a párt helyzete nagyon rossz. Ennek ellenére úgy látta - ami a valóságtól elszakadt, idealisztikus szemléletet tükrözött -, hogy minőségileg a legkiválóbbak tömörültek az MKPbe. Ugyanakkor a realitás talajára való visszatérést jelzi az osztály másik helyzetértékelése, amikor úgy látta, hogy a pedagógusok megnyerése nem könnyü feladat, mi több, igen negatív véleménye volt a csoportról, amikor azt fogalmazta meg, hogy a tanítók javíthatatlan „reakciós réteg”. A reakciós szó a kommunista terminológiában már ekkor a polgárit is jelentette. Az Értelmiségi Osztály ezen kívül hibának tartotta azt is, hogy nem vizsgálták a falusi egyházi tanítók magatartásának gyökereit, azt az anyagi és erkölcsi nyomást, amit szerintük az egyház gyakorolt. Az okok részbeni felületi magyarázata mellett az Értelmiségi Osztály a legfontosabb szempontra nem mutatott rá, ez pedig a tanítóság származása volt. A párt vezetésének látnia kellett volna, hogy a többségében középparaszti és részben kispolgári származású tanítóság szociológiailag olyan rétegből jött, hogy semmiféle szimpátiát nem tanúsított az MKP-val kapcsolatosan. Nem véletlen ezért, hogy elsősorban az FKGP-hez és kis részben az NPP-hez kötődtek. Az osztály értékelésének az a része már reálisabb volt, amelyben feltárta, hogy a helyi pártszervezetek merev tanítóellenes magatartást tanúsítottak, és ezért nem csoda, hogy csak elvétve akadt MKP-tag a tanítóság körében (PTI Arch. 274-24/2).

\section{A DIKTATÚRA KIÉPÜLÉSÉNEK IDŐSZAKA}

Az 1947-es évtől a kommunisták a pedagógusokkal már nemcsak a parasztság megnyerésének fontosságával összefüggésben kezdtek foglalkozni. Kiemelt jelentősége lett a hároméves tervnek, valamint az 1947-es, köztársaság-ellenes összeesküvésnek. Ezek a változások tükröződtek az Értelmiségi Osztály munkaterveiben is. Az 1947. február 1. - március 31. közötti időszakra vonatkozó teendők között általános feladat lett az „összeesküvés” politikai kihasználása az értelmiség felé. Továbbá nagy fontosságot kapott a hároméves terv propagálása és népszerüsítése a sajtóban és a szaksajtóban. A politikai befolyást akarták erö- 
síteni azzal, hogy a kommunista kezdeményezésủ státuszrendezést ki kívánták használni a pedagógusok megnyerésében. Célként fogalmazódott meg az is, hogy az MKP pedagógus munkaközösségeket alakít a köznevelés marxista szempontú kimunkálására (PTI Arch. 274-24/2).

Az Értelmiségi Osztály 1947. április 5. - július 1. közötti munkaterve megvalósítandó feladatnak tartotta az állami tankönyvkiadó létrehozását, a középiskolai rendszer átalakítását, valamint a pedagógusképzés reformját (PTI Arch. 274-24/2).

Azért, hogy a Magyar Kommunista Párt a tanítókat megnyerje, Lukács Sándor, a Magyar Pedagógus Szakszervezetek kommunista titkára 1947. március 19-én akcióprogram-javaslatot készített Farkas Mihálynak, az MKP főtitkárhelyettesének, a párt Szervező Bizottsága vezetőjének a falusi és tanyai tanítósággal kapcsolatosan indítandó programra. Az első számú javaslat Lukács Sándor kezdeményezésében a tanítók egyenjogúsítása volt az általános iskola többi pedagógusával. A kommunista szakszervezeti vezető továbbá kezdeményezte újabb tanítók kiküldését a falusi iskolákhoz. Tanítói lakásépítést is sürgetett, valamint gondoskodni akart a betegellátásról és az illetménykiosztás pontosságáról. Indítványozta a státuszrendezés teljes végrehajtását, a tanítói függetlenség biztosítását, a tanító gyerekek középiskolai ingyenes iskoláztatását és egy új beiskolázási törvényt. Azt is kezdeményezte, hogy a képviselői testületben a falusi tanítóknak juttassanak képviseletet. A javaslatban megfogalmazódott, hogy a Szabad Nép és a helyi pártlapok hetente egyszer foglalkozzanak a tanítóságért folytatott küzdelemmel. A Farkas Mihálynak készített javaslat arra is kitért, hogy a programot egy nemzetgyülési képviselö ismertesse a parlamentben. A kommunista szakszervezeti vezetőnek volt egy olyan elgondolása is, hogy az MKP minden falusi tanítóhoz juttasson el egy, A falusi iskola tanitóihoz címü, 4-6 oldalas füzetet, és a falusi pedagógus pártcsoport pedig falujárókat küldjön a falvakba (PTI Arch. 274-24/11).

Lukács Sándor javaslatainak is szerepük lehetett abban, hogy az MKP KV Szervezö Bizottsága 1947. június 18-án körlevelet küldött a pártszervekhez, hogy azok segítsék az embertelen viszonyok között élő tanítókat. A Szervező Bizottság úgy ítélte meg, ezáltal a tanítók közelebb kerülnek a demokráciához (népi), és elősegítik a párt befolyásának kiszélesítését. A továbbiakban úgy látta, hogy a tanítók megnyerése hozzájárul a parasztság megnyeréséhez. Mivel a Szervező Bizottság a tanítók nagy részét mindenképpen meg akarta nyerni, ezért be akarta léptetni a pártba. Azt akarta elérni, hogy a tanítók érezzék: az MKP a tanítók pártja (PTI Arch. 274-24/11).

A tanítók megnyeréséért folytatott kommunista politika most sem hozta meg a várt eredményt. A pedagógus politika eredménytelenségét támasztja alá az is, hogy 1947. júniusában a pedagógusok között mindösszesen 1800-2000 párttag volt. A párt pedagógus csoportjának Révai Józsefhez 1947. június 23 -án eljuttatott 
jelentéséből még rosszabb kép tárul elénk a kommunista befolyásról. A Pedagógus Szakszervezet 38000 tagjából a pártok részesedése a következőképpen alakult: MKP tag 4,35\%, SZDP 16\%, FKGP 13\%, NPP 5\%, PDP 4\%. A Pedagógus Csoport ezután abban bízott, hogy a státusztörvény augusztus 1-jei bevezetése életszínvonal-emelkedést eredményez a pedagógusok körében, ami a párttagság növekedéséhez is hozzájárulhat. A Magyar Kommunista Párt az augusztus 31-ei választásokig emelni szándékozott a pedagógusok közötti befolyását, és abban is reménykedett, hogy a 4,5-5\%-os MKP tagság 8-10\%-ra növelhető (PTI Arch. 274-24/11).

A pártmunka fő iránya ezután a pedagógusok pártba való beléptetése és a paszszív párttagok aktivizálása lett. Az Értelmiségi Osztály ugyanakkor kiadta, hogy a választások előtti héten csak tagszervezés legyen (PTI Arch. 274-24/11).

Az MKP gondosan készült a választásokra, az értelmiség között kiemelten foglalkozott a pedagógusokkal, azon belül is a tanítókkal. A párt negyvennégy pedagógust indított képviselőjelöltként (Jakab, 1979, 198.). Az eddig többnyire pedagógusellenes SZDP is aktív volt. Az FKGP választási programjában az értelmiség és ezen belül a pedagógusok nem kaptak különösebb hangsúlyt. Az NPP gyakorlatilag nem folytatott pedagógus politikát. Az ellenzéki pártok közül sem a Magyar Függetlenségi Pártnak, sem a Demokratikus Néppártnak nem volt a pedagógusokkal kapcsolatos politikája (Balogh-Izsák, 1977, 329-377.).

Az 1947-es választási adatok azt bizonyítják, hogy a munkáspártok, köztük az MKP értelmiségi befolyása lényegesen nem nőtt a „kékcédulás”, a csalásokat is alkalmazó választás után sem. A pedagógusok közötti kommunista befolyás is csupán minimális emelkedést mutatott, mert a választási kampány idején kb. száz fö lépett be a Kommunista Pártba. A pedagógusoknak a kommunisták számára nem megfelelő politikai-ideológiai véleményével is magyarázható, hogy 1947 öszén az MKP Értelmiségi Osztálya a Szervező Bizottságnak azt javasolta, hogy a pedagógusok részére komoly világnézeti tanfolyamokat indítsanak (PTI Arch. 274-24/2). A pedagógusok politikai orientációját és a kommunista befolyás helyzetét jól érzékelteti, ha az MKP-be való belépést összehasonlítjuk az összes pedagógus számával. A nyugdíjasokat is beleértve 1948-ban 45000 föről van szó, ebbe a számba az óvodai pedagógusoktól az egyetemi tanárokig valamennyien beletartoznak. Ebből a létszámból 1948 januárjában hozzávetőlegesen 2500 fő volt tagja a Magyar Kommunista Pártnak, ami a pedagógusok 6\%-át jelentette, ugyanakkor az SZDP tagság 12\%-ot, az FKGP pedig 7-8\%-ot képviselt (PTI Arch. 274-21/48; 274-24/11).

Mint látható a diktatúra kiépülésének hatására is csak igen lassú növekedés volt tapasztalható az MKP-ba belépő pedagógusok között. 1948 februárjában Magyarországon összesen 2800 párttag volt, ebből a legtöbben Csongrád megyében 200 fö, Hajdúban 200, Hevesben 120, Nógrádban 170, Szabolcsban pedig 120 fö. Optimista becslés szerint Budapesten 800 MKP-tag pedagógus volt. 
Bizonyos megyékben azonban még alacsonyabb volt a Kommunista Párt tagjainak a száma. Például Csanádban 39, Somogy, Fejér, Veszprém megyékben pedig csupán 25-30 fö. A rossz eredmények miatt a Magyar Kommunista Párt Köznevelési Bizottsága úgy döntött, hogy 1948 kora tavaszán sürgősen hozzá kell látni a taglétszám növeléséhez. A taglétszám növelését indítványozó, nyilvánosságot nem kapott Szervező Bizottsági és Értelmiségi Bizottsági döntések mellett az MKP lapjának 1948. március 12-i száma a Politikai Bizottság határozatára hivatkozva ugyanakkor fellépett a kollektív be- és átlépések ellen (Szabad Nép, 1948. március 12.). A kommunista terror légkörében megvalósított beléptetések eredményeként a Magyar Dolgozók Pártja létrejöttekor a tanárok 12-18\%-a már MKP-tag volt. A tanítókra koncentráló kommunista értelmiségpolitika nem mondható ilyen jónak.

A pedagógusok megnyerését elősegíteni szándékozó propaganda verbálisan a csoport anyagi helyzetének javításáért küzdött, ugyanakkor a nyilvánosságot nem kapott MKP-vélemény úgy ítélte meg, hogy a pedagógusokat nem lehet egy kalap alá venni a fizikai munkásokkal. A kommunistáknak az volt a felfogásuk, hogy a tanárok öt-hat órát dolgoznak, és így alkalmuk van külön munkát vállalni, ezért nem náluk, hanem a kevés jövedelmű fizikai munkásoknál kell az 1938-as szintet elérni (PTI Arch. 274-21/76). A kettős beszédet és politikát folytató kommunista gyakorlat igazságtalan volt, mert a pedagógusok anyagi helyzete, átlagos életszínvonala rendkívül rossz, illetve alacsony volt. A hivatalos statisztikák szerint a budapesti tanítói életszínvonal az 1938-as szintnek a 30\%-át érte csak el. A középiskolai tanároké 27,5\%, a fizikai dolgozóké ugyanakkor 70\% (PTI Arch. 274-24/11). A „kettős” játékot az ellenzék az 1945 augusztusában bevezetett státuszrendezéssel kapcsolatban leleplezte. Komlós Imre a Magyar Függetlenségi Párt képviselöje 1947. november 12-én interpellált a közoktatási miniszterhez a pedagógus státuszrendezés tárgyában. A politikus kifejtette, hogy az új pedagógus státusz a nevelői karnak nem felemelkedést, hanem lealacsonyodást, mellőzést jelent a többi közalkalmazottal szemben (Országgyűlés Naplója, I. 934.). Komlós ezért kéri a tényleges hatalmat gyakorló kommunista politikusokat, Révai Józsefet, az MKP vezető kultúrpolitikusát és Losonczi Gézát, a párt értelmiségi politikája egyik irányítóját, hogy emlékezzenek arra, amit a magyar nevelőkről korábban mondtak. A választások után Komlós mint politikai váltót jelképesen azt benyújtotta a Kommunista Pártnak (Országgyülés Naplója, I. 936.).

Komlós felvetésére még aznap, 1947. november 12-én reagált Lukács Sándor, az MKP képviselője. Az ellenzéki véleményekkel szemben Lukács szerint a korrekciókra szoruló részletek ellenére több nagy jelentőségü elvi döntést foglal magába a státusztörvény és a közalkalmazotti státusszal összehasonlítva az „új” státuszrendezés nemcsak biztosítja az egyenjogúságot, hanem bizonyos előnyöket is ad a nevelőknek, és lépés történt a pedagógusok nagyobb megbecsülése felé. A kommunista képviselő szerint a tanítói kezdő fizetés 50\%-os emelkedést mutat. 
Az ellenzéki felszólalásról Lukács Sándornak az volt a véleménye, hogy az felelötlen demagógia, amelyben megkísérelték a pedagógusokat a „demokratikus” kormány ellen irányítani. A kommunista érdekeket védő apologetikus beszéd elismerte, hogy a demokrácia többet tehetett volna az iskolaügy és a nevelők rossz anyagi helyzetének javítása érdekében. Az elmaradás okát abban látta, hogy az ország nehéz gazdasági helyzetében nem következhetett be azonnali változtatás, de a legkirívóbb kérelmeket orvosolták (Országgyülés Naplója I. 976., 969.).

Az 1947-es augusztusi kommunista státuszrendezés inkább volt sikertelen, mint eredményes, ezért nem segítette elö a pedagógusok körében az MKP befolyásának növekedését. Más értelmiségi csoportokkal - orvosok, mérnökök - öszszehasonlítva, a kommunisták politikai befolyása is szerénynek mondható. A pedagógusok párttagsága még 1948-ban is - különösen a tanítóké - igen alacsony volt. 1949-től elsősorban egzisztenciális okokból és politikai nyomás hatására már növekedés volt tapasztalható a pedagógusok között a pártba lépés terén.

IRODALOM

Rákosi S. - Szabó B. (1967): A Magyar Kommunista Párt és Szociáldemokrata Párt határozatai. Budapest: Kossuth Könyvkiadó

Balogh S. - Izsák L. (1977): Pártok és pártprogramok Magyarországon (1944-1948). Budapest: Tankönyvkiadó

Jakab M. (1979): Társadalmi változás és a magyar értelmiség. Budapest: Kossuth Könyvkiadó Gergely J. - Izsák L. (2000): A huszadik század története. Budapest: Pannónia Kiadó

\section{FORRÁSOK}

Kis Újság 1945-1948

Szabad Nép 1946-1948

Népszava 1945-1948

Magyar Közlöny 1945-1948

Nemzetgyülés Naplója (1952) III. kötet, VI. kötet. Hiteles Kiadás. Budapest

Országgyülés Naplója (1948) I-III. kötet. Hiteles Kiadás. Budapest: Athenaeum

Párttörténeti Intézet Archívuma (PTI Arch.) 